\title{
National guidelines on the management of venous thromboembolism: Joint guideline of the Turkish Society of Cardiovascular Surgery, National Society of Vascular and Endovascular Surgery, and Phlebology Society
}

\author{
Venöz tromboemboli yönetimine ilişkin ulusal kılavuzlar: Türk Kalp Damar Cerrahisi Derneği, \\ Ulusal Vasküler ve Endovasküler Cerrahi Derneği ve Fleboloji Derneği ortak kılavuzu
}

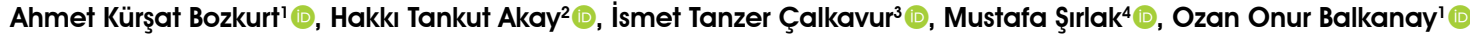

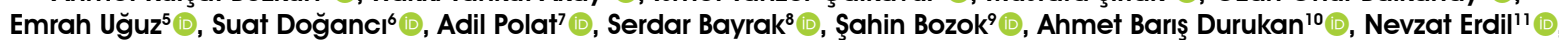

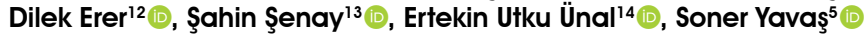 \\ Institution where the research was done: \\ Turkish Society of Cardiovascular Surgery, National Society of Vascular and Endovascular Surgery, and Phlebology Society \\ Author Affiliations: \\ 'Department of Cardiovascular Surgery, Istanbul University-Cerrahpasa, Cerrahpașa Faculty of Medicine, Istanbul, Turkey \\ ${ }^{2}$ Department of Cardiovascular Surgery, Başkent University, Faculty of Medicine, Ankara, Turkey \\ ${ }^{3}$ Department of Cardiovascular Surgery, Ege University, Faculty of Medicine, Izmir, Turkey \\ ${ }^{4}$ Department of Cardiovascular Surgery, Ankara University, Faculty of Medicine, Ankara, Turkey \\ ${ }^{5}$ Department of Cardiovascular Surgery, Health Sciences University, Ankara City Hospital, Ankara, Turkey \\ 'Department of Cardiovascular Surgery, Health Sciences University, Gülhane Faculty of Medicine, Ankara, Turkey \\ 'Department of Cardiovascular Surgery, Health Sciences University, Bağcilar Training and Research Hospital, Istanbul, Turkey \\ ${ }^{8}$ Department of Cardiovascular Surgery, Dokuz Eylül University, Faculty of Medicine, Izmir, Turkey \\ 9Department of Cardiovascular Surgery, Izmir Bakırçay University, Faculty of Medicine, Izmir, Turkey \\ ${ }^{10}$ Department of Cardiovascular Surgery, MediGüneș Salihli Private Hospital, Manisa, Turkey \\ "Department of Cardiovascular Surgery, Inönü University, Turgut Özal Medical Center, Malatya, Turkey \\ ${ }^{12}$ Department of Cardiovascular Surgery, Gazi University, Faculty of Medicine, Ankara, Turkey \\ ${ }^{13}$ Department of Cardiovascular Surgery, Acıbadem University, Faculty of Medicine, Istanbul, Turkey \\ ${ }^{14}$ Department of Cardiovascular Surgery, Hitit University, Faculty of Medicine, Çorum, Turkey
}

\section{ABSTRACT}

These evidence-based guidelines from the Turkish Society of Cardiovascula Surgery, National Society of Vascular and Endovascular Surgery, and Phlebology Society intend to support clinicians in best decisions regarding the treatment of venous thromboembolism (VTE). The Editor was selected by the three national societies and was tasked with the recruitment of the recognized panel. All financial support was solely derived from the sponsoring societies without the direct involvement of industry or other external stakeholders. The panel prioritized clinical questions and outcomes according to their importance for clinicians in terms of VTE. The panel agreed on 42 recommendations under 15 headings for the diagnosis, initial management, secondary prevention of VTE, and treatment of recurrent VTE events. Important recommendations included the use of ultrasonography, preference for home treatment over hospital treatment for uncomplicated VTE, preference for direct oral anticoagulants (DOACs) over vitamin $\mathrm{K}$ antagonists for primary treatment of cancer and non-cancer-related VTE, extended or indefinite anticoagulation with DOACs in selected high-risk patients. Early catheter-directed thrombectomy was recommended in only young symptomatic patients with a diagnosis of fresh iliofemoral deep vein thrombosis. Keywords: Anticoagulant therapy, cancer-related venous thromboembolism, catheter-directed thrombectomy, deep vein thrombosis, direct oral anticoagulants, evidence-based medicine, post-thrombotic syndrome, practice guideline, venous thromboembolism.
$\ddot{O} Z$

Türk Kalp Damar Cerrahisi Derneği, Ulusal Vasküler ve Endovasküler Cerrahi Derneği ve Fleboloji Derneği'nin kanıta dayalı kılavuzlarının amacı, venöz tromboemboli (VTE) tedavisine ilişkin hekimlerin en iyi kararı vermelerini desteklemektir. Üç ulusal dernek tarafından Editör seçilmiş olup, kararlaştırılmış panelin toplanması ile görevlendirilmiştir. Tüm finansal destekler, endüstri veya diğer harici tarafların doğrudan iştiraki olmaksızın, bütünüyle sponsor olan dernekler tarafından sağlanmıştır. Panelde hekimler için VTE açısından önemine göre klinik sorular ve sonuçlar önceliklendirilmiștir. Panelde VTE'nin tanısı, ilk tedavisi, ikincil korunması ve tekrarlayan VTE olaylarının tedavisi olmak üzere, 15 başlık altında 42 öneri üzerinde uzlaşılmıştır. Önemli öneriler arasında ultrasonografi kullanımı, komplike olmayan VTE'nin hastanede tedavisine kıyasla evde tedavi tercihi, primer kanser ve kanser ile ilişkili olmayan VTE tedavisinde vitamin $\mathrm{K}$ antagonistlerine kıyasla direkt oral antikoagülanların (DOAK) tercihi, belirli yüksek riskli hastalarda DOAK'lar ile uzun süreli veya süresiz antikoagülasyon yer almıştır. Erken dönemde kateter yönlendirmeli trombektomi, yalnızca taze iliofemoral derin ven tromboz tanısı konan genç semptomatik hastalarda önerilmiştir.

Anahtar sözcükler: Antikoagülan tedavi, kansere bağlı venöz tromboemboli, kateter yönlendirmeli trombektomi, derin ven trombozu, direkt oral antikoagülanlar, kanıta dayalı tıp, post trombotik sendrom, uygulama kılavuzu, venöz tromboemboli.

Received: May 13, 2021 Accepted: July 06, 2021 Published online: October 20, 2021

Correspondence: Ahmet Kürşat Bozkurt, MD. İstanbul Üniversitesi-Cerrahpaşa, Cerrahpaşa Tıp Fakültesi, Kalp ve Damar Cerrahisi Anabilim Dalı, 34098 Fatih, Istanbul, Türkiye. Tel: +90 532-246 0001 e-mail: akbozkurt@yahoo.com

Endorsed by the Turkish Society of Cardiovascular Surgery, National Society of Vascular and Endovascular Surgery, and Phlebology Society. Full text of the manual is electronically available at (http://www.e-bem.com/page/kilavuzlar/47) in Turkish language.

Bozkurt AK, Akay HT, Calkavur iT, Sirlak M, Balkanay OO, Uğuz E, et al. National guidelines on the management of venous thromboembolism: Joint guideline of the Turkish Society of Cardiovascular Surgery, National Society of Vascular and Endovascular Surgery, and Phlebology Society. Turk Gogus Kalp Dama 2021;29(4):562-576 
Venous thromboembolism (VTE) is a clinical picture that includes deep vein thrombosis (DVT) and pulmonary embolism (PE). The average annual incidence of VTE is around 104 to 183 per 100,000

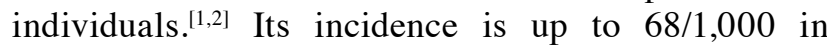
high-risk cases. ${ }^{[3]}$ The frequency of venous ulcers, which is the most important complication of postthrombotic syndrome (PTS), is 300 per 100,000 and $25 \%$ is caused by DVT. Although VTE recurrence rate varies depending on risk factors, it recurs at a rate of $20 \%$ in five years. Another possible complication in insufficiently treated VTE cases is chronic thromboembolic pulmonary hypertension $(\mathrm{CTEPH}){ }^{[2]}$ The main goal of the VTE treatment is to prevent PE, CTEPH, VTE recurrence, and PTS. This evidence-based guideline from the Turkish Society of Cardiovascular Surgery, National Society of Vascular and Endovascular Surgery, and Phlebology Society aims to support clinicians in best decisions regarding the treatment of VTE.

\section{Diagnosis}

In the presence of pain, swelling, edema and risk factors in the leg or upper extremity, VTE should be suspected and clinical evaluation should be made. Currently, color Doppler ultrasonography (USG) is the most effective method for the diagnosis of DVT. ${ }^{[4]}$ D-dimer also contributes to diagnosis and continuation of treatment in selected patients. ${ }^{[5]}$

\section{Treatment}

It is safe and cost-effective to treat DVT and possibly $\mathrm{PE}$ at home with low-molecular-weight heparin (LMWH) or direct oral anticoagulants (DOACs) in well-selected patients. If there is no problem in reaching the hospital or if the necessary support units are available at the patient's location, outpatient treatment should be considered as the initial approach. ${ }^{[8-10]}$

The following patients should be treated in the hospital:

- Phlegmasia cerulea dolens, phlegmasia alba dolens, symptomatic PE

- Patients at high risk of bleeding

- Active bleeding

- New surgery

- Active peptic ulcer

- Advanced hepatic disease (international normalized ratio [INR] $>1.3$ )

- Thrombocytopenia $(<100,000 / \mu \mathrm{L})$ or familial bleeding disease

- Body weight less than $45 \mathrm{~kg}$ or more than $100 \mathrm{~kg}$

- Children

- Complicated pregnant women

- Associated medical problems (e.g., dialysis)

Recommendation G-1

\begin{tabular}{|l|c|c|l|}
\hline Recommendation & Grade & Level of evidence & Key references \\
\hline $\begin{array}{l}\text { In all patients with clinical suspicion, color } \\
\text { Doppler USG is recommended as the first line } \\
\text { option in the diagnosis of DVT. }\end{array}$ & $\begin{array}{c}\text { Very strong recommendation } \\
\text { (I) }\end{array}$ & A & $\begin{array}{l}\text { Wittens et al }{ }^{[4]} \\
\text { Kakkos et al. }{ }^{[2]}\end{array}$ \\
\hline $\begin{array}{l}\text { Hereditary thrombophilia tests should only be } \\
\text { considered for unprovoked thrombus + VTE } \\
\text { history in the first-degree relatives. }\end{array}$ & $\begin{array}{c}\text { Strong recommendation } \\
\text { (IIa) }\end{array}$ & C & Moll ${ }^{[6]}$ \\
\hline $\begin{array}{l}\text { USG or D-dimer may be considered to detect } \\
\text { residual occlusion if extended therapy is } \\
\text { planned. }\end{array}$ & $\begin{array}{c}\text { Weak recommendation } \\
\text { (IIb) }\end{array}$ & B & Prandoni et al. ${ }^{[7]}$ \\
\hline USG: Ultrasonography; DVT: Deep vein thrombosis; VTE: Venous thromboembolism. & & \\
\hline
\end{tabular}

\section{Recommendation G-2}

\begin{tabular}{|l|c|c|l|}
\hline Recommendation & Grade & Level of evidence & Key references \\
\hline $\begin{array}{l}\text { When the conditions are suitable, ambulatory } \\
\text { care is recommended for patients with acute } \\
\text { DVT }\end{array}$ & Very strong recommendation & A & $\begin{array}{l}\text { Kearon et al. } \\
\text { Ortel et al. } \\
\text { Oth }\end{array}$ \\
\hline DVT: Deep vein thrombosis. & & \\
\hline
\end{tabular}


Anticoagulation is the mainstay of DVT treatment. The aim is to prevent the progression of thrombosis, new thrombosis, and PE. Classical treatment is to continue with vitamin $\mathrm{K}$ antagonist (VKA), when the target INR level is achieved for $>24 \mathrm{~h}$ after treatment with LMWH. ${ }^{\left[{ }^{[89}\right.}$ The target INR level should be 2 to 3 . Warfarin, originally developed as a poison, is an extremely effective and inexpensive drug. However, the treatment range is narrow, and drug-food interaction is common. Frequent INR examinations pose a serious problem for the healthcare system. The necessity of administering LMWHs by subcutaneous injection and drug-food interactions of oral VKAs have led to the standard treatment being far from ideal and more effective drugs to be developed. Among these, dabigatran, rivaroxaban, apixaban, and edoxaban are the drugs licensed in Turkey for the treatment of VTE as of February 2021.

Main advantages of DOACs are as follows: ${ }^{[9,11]}$

- Rapid onset of action due to short half-life, and rapid elimination after drug withdrawal

- Less drug-food interactions

- Not requiring laboratory examination for dose adjustment

- A single drug treatment is possible with rivaroxaban and apixaban (no need for early treatment with LMWH)

In the 2020 American Society of Hematology (ASH) guideline, the data of 28,876 patients diagnosed with VTE in 24 reviews and 12 randomized studies conducted with DOACs were evaluated. ${ }^{[9]}$ All studies compared a DOAC with standard therapy (LMWH followed by VKA). Mortality and VTE risk did not change with the use of DOACs. However, there was a decline in the frequency of major bleeding. The economic aspect was evaluated in 14 studies and DOAC treatment was found to be more cost-effective. Therefore, the 2020 ASH and the European Society of Vascular Surgery (ESVS) guidelines recommend that DOAC treatment should be preferred to standard treatment. However, standard therapy is recommended for patients using cytochrome P450 enzyme inhibitors. Dose adjustments should be considered according to the DOAC to be used in renal and hepatic insufficiency. Patients with antiphospholipid antibody syndrome, impaired absorption such as following bariatric surgery, a body weight of $>120 \mathrm{~kg}$, or extremely thin patients are not optimal DOAC candidates..$^{[2,9,11]}$

The most common anticoagulation protocol in our country is to start with LMWH and continue with VKA. However, in a study conducted in cardiology clinics by Ertaş et al., ${ }^{[12]}$ the time in therapeutic range (TTR) rate was found to be only $41.3 \%$, and this rate should be over $60 \%$ according to the world standards. Similarly, in a study conducted by Sargin et al., ${ }^{[13]}$ TTR was evaluated in 1,912 patients who were followed for more than three months. Only $34.3 \%$ of the patients had an INR value between 2 to 3 during follow-up and the average INR value was below 2 in $52.03 \%$ of the patients. The aforementioned authors also reported that the total hospital cost was $\$ 2,785$ for patients whose INR values could be kept at the desired level and \$3,192 for those who could not. ${ }^{[14]}$ It is obvious that keeping INR within the desired limits is not satisfactory in our country and poses a serious economic burden on the healthcare system. ${ }^{[12-14]}$

Recommendation G-3

\begin{tabular}{|c|c|c|c|}
\hline Recommendation & Grade & Level of evidence & Key references \\
\hline $\begin{array}{l}\text { It is recommended to treat DVT with dabigatran, } \\
\text { rivaroxaban, apixaban or edoxaban for } 3 \text { to } 6 \\
\text { months. }\end{array}$ & $\begin{array}{l}\text { Very strong recommendation } \\
\text { (I) }\end{array}$ & A & $\begin{array}{l}\text { Kakkos et al a. }{ }^{[16]} \\
\text { Ortel et al }{ }^{[9]} \\
\text { Kakkos et al. }{ }^{[2]}\end{array}$ \\
\hline $\begin{array}{l}\text { Direct oral anticoagulant therapy is preferred } \\
\text { to VKAs. }\end{array}$ & $\begin{array}{l}\text { Very strong recommendation } \\
\text { (I) }\end{array}$ & A & $\begin{array}{l}\text { Kakkos et al }{ }^{[16]} \\
\text { Ortel et al }{ }^{[9]} \\
\text { Kakkos et al. }{ }^{[2]}\end{array}$ \\
\hline $\begin{array}{l}\text { When treatment is to be performed with VKA; } \\
\text { LMWH + VKA are started together, when the } \\
\text { INR value is }>2 \text { and if this value is maintained } \\
\text { for } 24 \text { hours, treatment with VKA alone should } \\
\text { be continued. }\end{array}$ & $\begin{array}{l}\text { Very strong recommendation } \\
\text { (I) }\end{array}$ & A & Heit et al..$^{[1]}$ \\
\hline
\end{tabular}


In a study, the most common causes of drug-related hospitalization in patients over 65 years of age were warfarin $(33.3 \%)$, insulin (13.9\%), and antiaggregant drugs (13.3\%). ${ }^{[15]}$ Considering the current guidelines and the circumstances specific to our country, the following recommendations are presented in terms of the treatment of proximal acute DVT.

There are no randomized comparative studies of the four DOACs in use, and no preference is made in the guidelines. Dabigatran (80\%), apixaban (27\%), rivaroxaban $(35 \%)$ are excreted by renal clearance, and studies on apixaban and rivaroxaban in end-stage renal failure patients are still ongoing. In general, DOACs are not used in cases with severe hepatic failure; however, dabigatran is the least eliminated agent from the liver. In addition, the reasons for preference of the patient should be considered (i.e., necessity to be taken with food, single dose-double dose, or bleeding risk). It should be kept in mind that amiodarone, fluconazole, rifampin, and phenytoin interact with DOACs and alter the plasma levels.

\section{Cancer and Venous thromboembolism}

Malignancy is an important risk factor for VTE (3 to 7-fold increase in risk), and its incidence may reach 10 to $20 \%$ in these patients. ${ }^{[17,18]}$ Cancer can be diagnosed in 4 to $12 \%$ of DVTs of uncertain cause within the following months. ${ }^{[18]}$ A detailed examination and screening for occult cancer are not recommended for all patients. ${ }^{[2,18,19]}$ Cancer-related risk factors are summarized in Table 1.

It has been well documented that VKAs are not ideal in VTE patients with cancer, since they have a 3.2-fold higher VTE risk and 2.3-fold higher bleeding risk, compared to patients without cancer. Therefore, LMWH was considered the gold standard until DOAC studies were completed. However, all LMWHs can be applied by injection only, and the rate of patients completing this recommended treatment for six months was reported as only $61 \%$ with oral anticoagulants and $37 \%$ with LMWH. Patients usually refrain from injection. ${ }^{[20-22]}$

\section{Recommendation G-4}

\begin{tabular}{|c|c|c|c|}
\hline Recommendation & Grade & Level of evidence & Key references \\
\hline $\begin{array}{l}\text { Clinical examination and sex-specific cancer } \\
\text { screening are recommended in unprovoked } \\
\text { VTE cases (e.g., PSA). }\end{array}$ & $\begin{array}{l}\text { Very strong recommendation } \\
\text { (I) }\end{array}$ & A & $\begin{array}{l}\text { Klein et al. }{ }^{[19]} \\
\text { Kakkos et al. } .^{[2]}\end{array}$ \\
\hline
\end{tabular}

Table 1. Risk factors for cancer-related VTE

\begin{tabular}{|c|c|c|}
\hline Group & Risk factor & Increased risk \\
\hline \multirow{4}{*}{ Tumor-related } & Region & Brain, pancreas, stomach, ovary, lung, myeloma, lymphoma, kidney \\
\hline & Cancer duration & $<3$ months from diagnosis \\
\hline & Stage & High \\
\hline & Phase & Advanced \\
\hline \multirow[t]{2}{*}{ Patient-related } & Non-cancer-related & $\begin{array}{l}>40 \text { years of age, female sex, concomitant diseases, infection, obesity, } \\
\text { anemia, dehydration, personal or family history of VTE, hereditary or } \\
\text { acquired thrombophilia, concurrent acute illness, lung disease, kidney } \\
\text { disease, long-term immobility, smoking }\end{array}$ \\
\hline & Cancer-related & $\begin{array}{l}\text { Thrombocytosis, leukocytosis, anemia, hospitalization, acquired, protein } \mathrm{C} \\
\text { resistance }\end{array}$ \\
\hline \multirow{3}{*}{ Treatment-related } & Surgical & $>30$ min laparotomy or laparoscopy; major abdominal or pelvic surgery \\
\hline & Pharmacological & $\begin{array}{l}\text { Aggressive chemotherapy, antiangiogenic drugs, growth factors, blood } \\
\text { products }\end{array}$ \\
\hline & Venous catheter associated & $\begin{array}{l}\text { Central venous catheter, femoral venous catheter, peripheral intravenous } \\
\text { catheter }\end{array}$ \\
\hline
\end{tabular}

\footnotetext{
VTE: Venous thromboembolism.
} 
There is a significant number of cancer patients in the first Phase 3 registry studies of DOACs that is the scope of a meta-analysis. Interestingly, a $35 \%$ reduction in VTE risk was found with the use of DOACs without any significant change in the mortality rates. ${ }^{[23]}$ In addition, a $36 \%$ reduction in VTE risk and a 55\% reduction in bleeding risk were reported with DOACs, which are factor Xa inhibitors. After these promising data, cancer-specific DOAC studies started to be published..$^{[24-27]}$ All of these studies were designed as open-label for ethical reasons, and the comparator was dalteparin. In all studies, DOACs were used at standard doses, and dalteparin was used at the standard dose for one month, but then continued with a $25 \%$ lower dose. While the rate of major bleeding was not significantly different with rivaroxaban, the rate of clinically relevant non-major (CRNM) bleeding was high. Edoxaban showed the same effect as dalteparin, except for an increasing trend in major bleeding. Apixaban was equally found to be effective and did not affect major and CRNM bleeding rates. The increase in bleeding rates observed in the first two DOAC studies is most likely related to the reduction of the dalteparin dose after one month, despite standard DOAC dosage. Previous studies have specifically reported an increase in bleeding with DOACs in gastrointestinal tumors, while a recent apixaban study does not support this finding. ${ }^{[28]}$

The recommendations in the current ESVS (January 2021) ${ }^{[2]}$ and ASH (March 2021) guidelines ${ }^{[19]}$ are not compatible. The ESVS guidelines prioritize a more traditional approach and recommend LMWH treatment as a priority in cancer patients. However, the ASH guidelines recommend DOAC as the firstline treatment. In all of them, it is recommended to use DOACs carefully in gastrointestinal system tumors. These data are depicted in Table 2.

In addition to all these information and guidelines, recommendations in the treatment of cancer-related VTE are summarized under G-5 in this guideline, taking into account the recent study reported by Ageno et al. ${ }^{[28]}$

Table 2. ESVS and ASH recommendations in the treatment of cancer-related VTE

\begin{tabular}{|c|c|}
\hline European Society of Vascular Surgery ${ }^{[2]}$ & American Society of Hematology ${ }^{[19]}$ \\
\hline $\begin{array}{l}\text { LMWH is recommended in cases of cancer associated VTE } \\
\text { (IA recommendation) }\end{array}$ & $\begin{array}{l}\text { In the initial treatment (first } 7 \text { days) DOAC (apixaban or } \\
\text { rivaroxaban) or LMWH can be used }\end{array}$ \\
\hline $\begin{array}{l}\text { After three months of LMWH, switch to oral anticoagulant } \\
\text { for extended therapy (I C recommendation) }\end{array}$ & $\begin{array}{l}\text { In the short-term VTE treatment ( } 3-6 \text { months), DOAC } \\
\text { (apixaban, edoxaban, or rivaroxaban) is preferred to LMWH } \\
\text { and VKA. Preferred to LMWH and VKA. }\end{array}$ \\
\hline $\begin{array}{l}\text { In selected patients, an approved DOAC can be used at } \\
\text { all stages if the tumor is not in the gastrointestinal or } \\
\text { genitourinary system (IIa A recommendation) }\end{array}$ & $\begin{array}{l}\text { In the presence of active cancer and VTE, treatment with } \\
\text { DOAC or LMWH is recommended after } 6 \text { months. }\end{array}$ \\
\hline
\end{tabular}

ESVS: European Society of Vascular Surgery; ASH: American Society of Hematology; VTE: Venous thromboembolism; LMWH: Low molecular weight heparin; DOAC: Direct oral anticoagulant; VKA: Vitamin K antagonist.

Recommendation G-5

National guideline recommendations for the treatment of cancer-related VTE

\begin{tabular}{|c|c|c|c|}
\hline Recommendation & Grade & Level of evidence & Key references \\
\hline $\begin{array}{l}\text { LMWH is recommended in cases of VTE due } \\
\text { to cancer. }\end{array}$ & $\begin{array}{l}\text { Very strong recommendation } \\
\text { (I) }\end{array}$ & A & $\begin{array}{l}\text { Kakkos et al. }^{[2]} \\
\text { Ortel et al. } .^{\left[{ }^{2]}\right.} \\
\text { Kirkilesis et al. }{ }^{[23]}\end{array}$ \\
\hline $\begin{array}{l}\text { Use of DOAC (apixaban*, edoxaban, } \\
\text { rivaroxaban) is recommended for the treatment } \\
\text { of cancer-related VTE. }\end{array}$ & $\begin{array}{l}\text { Very strong recommendation } \\
\text { (I) }\end{array}$ & A & $\begin{array}{l}\text { Kakkos et al. }{ }^{[2]} \\
\text { Ortel et al. } .^{[9]} \\
\text { Kirkilesis et al. }{ }^{[23]} \\
\text { Agnelli et al. }{ }^{[27]} \\
\text { Ageno et al. }{ }^{[28]}\end{array}$ \\
\hline
\end{tabular}

VTE: Venous thromboembolism; LMWH: Low molecular weight heparin; DOAC: Direct oral anticoagulant; * Apixaban may be preferred primarily in carefully selected patients with gastrointestinal system tumors. 


\section{What is the most appropriate treatment for venous thromboembolism in pregnancy?}

There is insufficient evidence to make recommendations for the treatment of VTE in pregnant women. Pregnant women are five times more likely to have VTE than non-pregnant women. The VKAs cross the placenta in pregnant women and may cause embryopathy between the $6^{\text {th }}$ and $12^{\text {th }}$ week and bleeding at birth. However, standard heparin and LMWH do not cross the placenta. In general, DOACs are not recommended during pregnancy. ${ }^{[1]}$ Table 3 summarizes the anticoagulant option in different patient groups.

\section{Duration of anticoagulant therapy}

In the standard approach, treatment of VTE is discontinued after three to six months, if the patient does not have any risk factors such as thrombophilia. However, in such cases, the risk of rethrombosis is not low and the risk of PTS increases significantly after rethrombosis. The possibility of recurrence in different risk groups is shown in Table $4 .^{[5,8]}$

After three to six months of DVT treatment, the decision to continue anticoagulation should be made with the likelihood of recurrence in the risk groups above. Two other important factors to be considered clinically are the patient's sex and D-dimer values.

Table 3. Factors that may affect the choice of anticoagulant drugs

\begin{tabular}{ll}
\hline Factor & Drug of choice \\
\hline Cancer & LMWH and DOAC \\
Single dose request & Rivaroxaban, edoxaban, VKA \\
Reluctance to parenteral therapy & Rivaroxaban, apixaban \\
Liver disease and coagulopathy & LMWH \\
Renal insufficiency (creatinine clearance rate $<30 \mathrm{~mL} / \mathrm{min})$ & VKA \\
Coronary artery disease & VKA, rivaroxaban, apixaban \\
Pregnancy & LMWH \\
Neutralization possibility & Standard heparin \\
Dyspepsia and risk of GIS bleeding & Apixaban \\
\hline
\end{tabular}

LMWH: Low molecular weight heparin; DOAC: Direct oral anticoagulant; VKA: Vitamin K antagonist; GIS: Gastrointestinal system.

\section{Recommendation G-6}

\begin{tabular}{|c|c|c|c|}
\hline Recommendation & Grade & Level of evidence & Key references \\
\hline $\begin{array}{l}\text { In DVT cases occurring during pregnancy, } \\
\text { LMWH is recommended in three months } \\
\text { therapeutic dose. It is recommended to continue } \\
\text { for at least six weeks after birth. }\end{array}$ & $\begin{array}{l}\text { Very strong recommendation } \\
\text { (I) }\end{array}$ & B & $\begin{array}{l}\text { Greer and } \\
\text { Nelson-Piercy }{ }^{[29]} \\
\text { Kakkos et al. }{ }^{[2]}\end{array}$ \\
\hline
\end{tabular}

Table 4. Possibility of recurrence in risk groups

\begin{tabular}{lll}
\hline Risk factor & Risk of recurrence & \\
\hline Temporary risk factor & $3-5 \%$ a year & Surgery, major internal disease \\
Non-surgical temporary risk factor & $15 \%-5$ years & Long travel, estrogen therapy, pregnancy, leg trauma \\
Idiopathic or demonstrated thrombophilia & $30 \%-5$ years & + AT, PC, PS deficiency, homozygous \\
Cancer & $15 \%$ for each year \\
Isolated distal DVT & $1 / 2$ reduction in all ratios above \\
Idiopathic DVT & $1 / 2$ increase in all the above rates & \\
\hline
\end{tabular}

AT: Atherothrombin; PC: Protein C; PS: Protein S; DVT: Deep vein thrombosis. 
The recurrence risk in male patients is $75 \%$ higher than women. ${ }^{[30]}$ If D-dimer measurement one month after the cessation of treatment is still high, the possibility of recurrence is twice as high. ${ }^{[31]}$ The risk multiplies in men and patients with high D-dimer values. Clinicians usually avoid prolonged treatment due to the risk of excessive bleeding associated with the use of VKAs. However, researches are ongoing due to the high risk of rethrombosis. ${ }^{[32-37]}$ In comparative studies with DOACs, $2.5 \mathrm{mg}$ of apixaban, 10 or $20 \mathrm{mg}$ of rivaroxaban, and $60 \mathrm{mg}$ of edoxaban appear to be superior for the benefit-risk relationship. The acetylsalicylic acid (ASA) was compared with placebo in the WARFASA, ASPIRE, and INSPIRE studies. Mainly, with a minimal increase in bleeding risk, an $1 / 3$ increase of effect was achieved. ${ }^{[38-40]}$

The Turkish National guideline was published in $2016^{[41]}$ and, in light of the information in the 2020 ASH and 2021 ESVS guidelines, the recommendations were updated as follows: ${ }^{[2,9]}$

\section{Venous thromboembolism in children}

In children, the 2018 ASH guidelines recommend LMWH or VKA in symptomatic cases of DVT and PE, despite the scarcity of data. ${ }^{[45]}$ In the dabigatran DIVERSITY study published in December 2020, 328 children $(<18$ years of age) were either treated with standard therapy (LMWH, VKA or fondaparinux)

Recommendation G-7

\begin{tabular}{|c|c|c|c|}
\hline Recommendation & Grade & Level of evidence & Key references \\
\hline $\begin{array}{l}\text { In selected cases of provoked proximal DVT, } \\
\text { if there is a persistent risk factor other than } \\
\text { cancer, extended therapy should be considered } \\
\text { (after assessing the risk of thrombosis and } \\
\text { bleeding). }\end{array}$ & $\begin{array}{l}\text { Strong recommendation } \\
\text { (IIa) }\end{array}$ & $\mathrm{C}$ & Kakkos et al. ${ }^{[2]}$ \\
\hline $\begin{array}{l}\text { In selected cases of provoked proximal DVT, if } \\
\text { there is a minor transient risk factor, extended } \\
\text { therapy may be considered (after assessing the } \\
\text { risk of thrombosis and bleeding). }\end{array}$ & $\begin{array}{l}\text { Weak recommendation } \\
\text { (IIb) }\end{array}$ & $\mathrm{C}$ & Prins et al. ${ }^{[42]}$ \\
\hline $\begin{array}{l}\text { In the presence of unprovoked DVT, if the } \\
\text { bleeding risk is low or moderate, extended } \\
\text { anticoagulation is recommended by periodically } \\
\text { evaluating the bleeding risk. }\end{array}$ & $\begin{array}{l}\text { Very strong recommendation } \\
\text { (I) }\end{array}$ & A & Kakkos et al. ${ }^{[2]}$ \\
\hline $\begin{array}{l}\text { DOAC should be preferred to VKA for extended } \\
\text { anticoagulation. }\end{array}$ & $\begin{array}{l}\text { Strong recommendation } \\
\text { (IIa) }\end{array}$ & B & $\begin{array}{l}\text { Ortel et al. }{ }^{[9]} \\
\text { Kakkos et al. }{ }^{[2]} \\
\end{array}$ \\
\hline $\begin{array}{l}\text { Apixaban, rivaroxaban or edoxaban should be } \\
\text { considered if extended treatment is considered } \\
\text { after six months in a patient with provoked } \\
\text { DVT. }\end{array}$ & $\begin{array}{l}\text { Strong recommendation } \\
\text { (IIa) }\end{array}$ & B & $\begin{array}{l}\text { Agnelli et al. }{ }^{[43]} \\
\text { Weitz et al. }{ }^{[35]}\end{array}$ \\
\hline $\begin{array}{l}\text { ASA may be considered in patients not using } \\
\text { oral anticoagulants. }\end{array}$ & $\begin{array}{l}\text { Weak recommendation } \\
\text { (IIb) }\end{array}$ & $\mathrm{C}$ & $\begin{array}{l}\text { Becattini et al. }{ }^{[38]} \\
\text { Brighton et al. }{ }^{[39]} \\
\text { Simes et al. } .^{[40]} \\
\end{array}$ \\
\hline $\begin{array}{l}\text { In the presence of a second or subsequent } \\
\text { unprovoked DVT, extended therapy is } \\
\text { recommended. }\end{array}$ & $\begin{array}{l}\text { Very strong recommendation } \\
\text { (I) }\end{array}$ & B & Kakkos et al. ${ }^{[2]}$ \\
\hline $\begin{array}{l}\text { If DVT develops during treatment in the patient } \\
\text { whose medication is certain, anticoagulant } \\
\text { regimen may be changed, LMWH dose may } \\
\text { be increased, DOAC treatment dose may be } \\
\text { increased, and a higher INR may be targeted } \\
\text { for the VKA dose. }\end{array}$ & $\begin{array}{l}\text { Weak recommendation } \\
\text { (IIb) }\end{array}$ & $\mathrm{C}$ & Schulman et al. ${ }^{[44]}$ \\
\hline
\end{tabular}


or with dabigatran adjusted for age and weight. ${ }^{[46]}$ Bleeding was reported as $24 \%$ with standard therapy and as $22 \%$ with dabigatran, and major bleeding rates were not significantly different. Dabigatran was found to have a comparable efficacy with standard therapy. Similar efficacy was reported with rivaroxaban in pediatric patients, and it was approved for use in the United Kingdom healthcare system in February 2021. ${ }^{[47]}$

\section{Direct oral anticoagulants and neutralization}

The DOAC neutralization may be required for emergency intervention in some patients. Options are summarized below. ${ }^{[48,49]}$

The antidote strategy recommended by the American College of Cardiology (ACC) in bleeding due to various anticoagulants is summarized below (Table 5). ${ }^{[50]}$

\section{Acute isolated distal DVT}

Proximal progression and PE are seen in $15 \%$ of cases with distal isolated DVT. The following factors increase the risk of proximal progression and $\mathrm{PE}:{ }^{[5]}$ positive $\mathrm{D}$-dimer, thrombus longer than $5 \mathrm{~cm}$ along the vein, thrombus diameter greater than $7 \mathrm{~cm}$, thrombus close to the proximal veins, active cancer, and a previous history of VTE. In a Cochrane analysis reported by Kirkilesis et al., ${ }^{[51]}$ VKA reduced the risk of recurrent VTE, although its effect on PE was not demonstrated. While the risk did not increase in major bleeding, a minimal increase was found in CRNM bleeding. With six-week and three-month anticoagulation, recurrent DVT was found to be $5.8 \%$ and $13.9 \%$, respectively and there was no significant increase in bleeding. In the light of these data, the national guideline recommendations are as follows:

\section{Superficial vein thrombosis (SVT)}

In the POST study, deep vein progression or PE was detected in $25 \%$ of patients with SVT. ${ }^{[53]}$ In other studies, the possibility of thromboembolism was reported to be between 6.2 and $22.6 \% .{ }^{[2]}$ These data indicate that SVT is not innocent. Cancer, thrombus close to the saphenofemoral (SFJ) or saphenopopliteal junction (SPJ), varicose veins, and thrombosis are the risk factors. ${ }^{[54]}$

In a meta-analysis conducted in 2019, Duffett et al. ${ }^{[55]}$ reviewed data from 6,862 patients receiving SVT treatment. During follow-up, the VTE rate

Table 5. Oral anticoagulant neutralization recommendations

\begin{tabular}{ll}
\hline Oral anticoagulant & Neutralization recommendations \\
\hline Vitamin K antagonist & $\begin{array}{l}\text { Give 4F-PCC (4 factor prothrombin complex concentrate), } \\
\text { otherwise give fresh frozen plasma }\end{array}$ \\
Factor IIa inhibitor (dabigatran) & Apply idarucizumab \\
& If it is not available, issue PCC or aPCC (activated PCC) \\
& If medication is taken within 2-4 hours, consider activated charcoal. \\
$\begin{array}{ll}\text { FXa inhibitors (apixaban, betrixaban, edoxaban, and } \\
\text { rivaroxaban) }\end{array}$ & Give Andexanet alpha \\
& If it is not available, PCC or aPCC \\
& If medication is taken within 2-4 hours, consider activated charcoal.
\end{tabular}

PCC: Prothrombin complex concentrate; If PCC is used for vitamin K antagonist neutralization, vitamin K must be added.

\begin{tabular}{|l|c|c|l|}
\hline Recommendation G-8 & Grade & Level of evidence & Key references \\
\hline Recommendation & A & Kirkilesis et al. ${ }^{[51]}$ \\
\hline $\begin{array}{l}\text { In the presence of distal DVT, three months } \\
\text { treatment is preferred to a shorter treatment. }\end{array}$ & $\begin{array}{c}\text { Very strong recommendation } \\
\text { (I) }\end{array}$ & C & ${\text { Kakkos et al. }{ }^{[16]}}^{\text {(I) }}$ \\
\hline $\begin{array}{l}\text { DOACs are preferred to LMWH. The other } \\
\text { option is VKA. }\end{array}$ & $\begin{array}{c}\text { Very strong recommendation } \\
\text { (I) }\end{array}$ & C & Galanaud et al. ${ }^{[52]}$ \\
\hline $\begin{array}{l}\text { In the presence of symptomatic calf DVT plus } \\
\text { cancer, treatment for more than three months is } \\
\text { recommended. }\end{array}$ & \begin{tabular}{c} 
Very strong recommendation \\
\hline DVT: Deep vein thrombosis; DOAC: Direct oral anticoagulant; LMWH: Low molecular weight heparin; VKA: Vitamin K antagonist.
\end{tabular} \\
\hline
\end{tabular}


(per 100 patient years) was reported as 12.1 with LMWH, 1.4 with fondaparinux, and 9.6 with nonsteroidal anti-inflammatory drugs (NSAIDs). While fondaparinux was evaluated in a very well standardized study, there are substantial differences in duration and dose in LMWH and NSAID patients. Fondaparinux treatment is relatively expensive and requires subcutaneous injection. Rivaroxaban can be used, as it is more cost-effective and has been shown to be at least as effective as fondaparinux. ${ }^{[56]}$

\section{Upper extremity deep vein thrombosis}

In DOAC Phase 3 studies, upper extremity DVT cases were not included, and there are no specific data available on this subject. In a prospective review of 210 patients treated in the Mayo Clinic

\section{Recommendation G-9}

\begin{tabular}{|c|c|c|c|}
\hline Recommendation & Grade & Level of evidence & Key references \\
\hline $\begin{array}{l}\text { Anticoagulation is not recommended in isolated } \\
\text { superficial vein thrombosis of }<5 \mathrm{~cm} \text { in lower } \\
\text { extremity if there is no risk such as malignancy, } \\
\text { thrombophilia, or proximity to the deep venous } \\
\text { system. }\end{array}$ & $\begin{array}{l}\text { Not recommended } \\
\text { (III) }\end{array}$ & $\mathrm{C}$ & Kakkos et al. ${ }^{[32]}$ \\
\hline $\begin{array}{l}\text { In the lower extremity superficial vein } \\
\text { thrombosis case, when acute inflammation and } \\
\text { prothrombotic process improve, endovenous } \\
\text { ablation procedures should be considered } \\
\text { (>3 months). }\end{array}$ & $\begin{array}{l}\text { Strong recommendation } \\
\text { (IIa) }\end{array}$ & $\mathrm{C}$ & Kakkos et al. ${ }^{[32]}$ \\
\hline $\begin{array}{l}\text { Fondaparinux } 2.5 \mathrm{mg} \text { or rivaroxaban } 10 \mathrm{mg} \\
\text { recommended if superficial vein thrombosis of } \\
\text { the lower extremity is }>3 \mathrm{~cm} \text { from the deep vein } \\
\text { and is }>5 \mathrm{~cm} \text { long }\end{array}$ & $\begin{array}{l}\text { Very strong recommendation } \\
\text { (I) }\end{array}$ & B & $\begin{array}{l}\text { Decousus et al. }{ }^{[57} \\
\text { Beyer-Westendorf } \\
\text { et al. }{ }^{[56]}\end{array}$ \\
\hline $\begin{array}{l}\text { If the lower extremity superficial vein } \\
\text { thrombosis is }>3 \mathrm{~cm} \text { from the deep vein and }>5 \\
\mathrm{~cm} \text { in length, LMWH should be considered as } \\
\text { an alternative. }\end{array}$ & $\begin{array}{l}\text { Strong recommendation } \\
\text { (IIa) }\end{array}$ & B & $\begin{array}{l}\text { Duffett et al. }{ }^{[55]} \\
\text { Nikolakopoulos } \\
\text { et al. }{ }^{[58]}\end{array}$ \\
\hline $\begin{array}{l}\text { If the lower extremity superficial vein } \\
\text { thrombosis is }>3 \mathrm{~cm} \text { from the deep vein and } \\
>5 \mathrm{~cm} \text { in length, anticoagulation for } 45 \text { days is } \\
\text { recommended. }\end{array}$ & $\begin{array}{l}\text { Very strong recommendation } \\
\text { (I) }\end{array}$ & B & $\begin{array}{l}\text { Decousus et al. }{ }^{[57]} \\
\text { Beyer-Westendorf } \\
\text { et al. } \\
\text { Duffett et al. }^{[55]} \\
\end{array}$ \\
\hline $\begin{array}{l}\text { Therapeutic anticoagulation is recommended if } \\
\text { the lower extremity superficial vein thrombosis } \\
\text { is }<3 \mathrm{~cm} \text { from the deep vein. }\end{array}$ & $\begin{array}{l}\text { Very strong recommendation } \\
\text { (I) }\end{array}$ & $\mathrm{C}$ & Kakkos et al. ${ }^{[32]}$ \\
\hline $\begin{array}{l}\text { Three months of treatment may be considered } \\
\text { in clinically or anatomically risky patients. }\end{array}$ & $\begin{array}{l}\text { Weak recommendation } \\
\text { (IIb) }\end{array}$ & $\mathrm{C}$ & $\begin{array}{l}\text { Nikolakopoulos } \\
\text { et al. }{ }^{[58]}\end{array}$ \\
\hline
\end{tabular}

\section{Recommendation G-10}

\begin{tabular}{|l|c|c|l|}
\hline Recommendation & Grade & Level of evidence & Key references \\
\hline $\begin{array}{l}\text { Anticoagulation with DOAC for three months } \\
\text { is recommended in the presence of primary } \\
\text { upper extremity DVT. }\end{array}$ & $\begin{array}{l}\text { Very strong recommendation } \\
\text { (I) }\end{array}$ & Houghton et al. ${ }^{[59}$ \\
Schastlivtsev et al. ${ }^{[60]}$ \\
$\begin{array}{l}\text { Thrombolysis can be considered in the first } \\
\text { two weeks in a young and active patient with } \\
\text { serious complaints. }\end{array}$ & $\begin{array}{c}\text { Weak recommendation } \\
\text { (IIb) }\end{array}$ & Illig and Doyle ${ }^{[61]}$ \\
\hline DOAC: Direct oral anticoagulant; DVT: Deep vein thrombosis. & & \\
\hline
\end{tabular}


between 2013 and 2019, 63 patients were treated with apixaban, 39 patients with rivaroxaban, and 108 patients with LMWH and/or warfarin. ${ }^{[59]}$ The series included 51\% catheter-related DVT, $60 \%$ cancer, and $14 \% \mathrm{PE}$ and no significant difference was found in the treatment efficacy. Three major bleeding was detected in the LMWH and/or warfarin group, but not in the DOAC group. In a rivaroxaban study, 30 patients were followed for six months and recurrent thrombosis was observed. ${ }^{[60]}$ While two CRNMs and two minor hemorrhages were reported, complete recanalization was found in the affected vein in all patients. Thrombolytic therapy can be considered in well-selected patients. ${ }^{[61]}$

\section{Catheter-directed thrombolysis}

There are 11 reviews and 19 randomized studies related to the treatment of acute proximal DVT with thrombolytic therapy + anticoagulant or anticoagulant alone..$^{[9]}$ Thrombolytic therapy has no significant effect on the mortality rate in DVT patients, but may reduce the risk of PTS, despite high major and intracranial bleeding rates. Although the increase in major bleeding is seen in systemic and catheterdirected thrombolysis, it does not reach statistical significance.

Currently, catheter-directed pharmacomechanical thrombolysis is a great debate in the treatment of VTE. The CAVENT study yielded positive results, but the ATTRACT and CAVA studies demonstrated no benefit. ${ }^{[62-64]}$ To date, a decrease in PTS was reported in seven series; however, no significant difference was found in one study (ATTRACT study). On the other hand, there is widespread controversy regarding the ATTRACT methodology. In the 2020 ASH guideline, thrombolytic therapy is recommended in a young patient with a low risk of bleeding, with extremity threat (phlegmasia cerulea dolens), and symptomatic DVT in the iliac and common femoral vein, despite a low level of evidence. ${ }^{[9]}$ When the results of 427 patients in three reviews and five controlled studies were examined, bleeding was found to be lower with catheter-directed

\section{Recommendation G-11}

\begin{tabular}{|l|c|c|l|}
\hline Recommendation & Grade & Level of evidence & Key references \\
\hline $\begin{array}{l}\text { Early thrombectomy should be considered in } \\
\text { selected symptomatic patients with a diagnosis } \\
\text { of iliofemoral DVT. }\end{array}$ & $\begin{array}{c}\text { Strong recommendation } \\
\text { (IIa) }\end{array}$ & A & $\begin{array}{l}\text { Enden et al. }{ }^{[62]} \\
\text { Vedantham et al. }^{[63]} \\
\text { Notten et al. } .^{[64]} \\
\text { Kahn et al. } .^{[6]}\end{array}$ \\
\hline $\begin{array}{l}\text { Early thrombus removal is not recommended } \\
\text { in cases limited to femoral, popliteal and calf } \\
\text { veins. }\end{array}$ & $\begin{array}{c}\text { Not recommended } \\
\text { (III) }\end{array}$ & B & Kearon et al. ${ }^{[6]]}$ \\
\hline $\begin{array}{l}\text { Standardanticoagulant therapy is recommended } \\
\text { for these patients. }\end{array}$ & $\begin{array}{c}\text { Very strong recommendation } \\
\text { (I) }\end{array}$ & C & Kearon et al. ${ }^{[6]]}$ \\
\hline $\begin{array}{l}\text { Catheter-directed thrombolysis should be } \\
\text { preferred to systemic thrombolysis. }\end{array}$ & $\begin{array}{c}\text { Strong recommendation } \\
\text { (IIa) }\end{array}$ & B & ASH 2020 \\
\hline DVT: Deep vein thrombosis. & & & \\
\hline
\end{tabular}

Table 6. Absolute and relative contraindications of thrombolytic therapy

\begin{tabular}{ll}
\hline Absolute contraindications & \\
Previous hemorrhagic stroke & Intracranial disease \\
Active non-menstrual bleeding & Ischemic stroke within three months \\
Tendency to bleed & Cerebral tumor \\
Relative contraindications & \\
Recent noncranial bleeding & Blood pressure $>180 / 110 \mathrm{mmHg}$ \\
Active peptic ulcer & Recent surgery \\
Uncompressible vascular bleeding & Pregnancy \\
New trauma from 2-4 weeks ago & \\
\hline
\end{tabular}




\section{Recommendation G-12}

\begin{tabular}{|l|c|c|l|}
\hline Recommendation & Grade & Level of evidence & Key references \\
\hline $\begin{array}{l}\text { Temporary IVC filter is recommended } \\
\text { in patients for whom anticoagulation is } \\
\text { contraindicated and in patients who have } \\
\text { recurrent venous thromboembolism despite } \\
\text { adequate anticoagulation. }\end{array} \quad$ (I) & & Kaufman et al. ${ }^{[69]}$ \\
\hline IVC: Inferior vena cava. & & & \\
\hline
\end{tabular}

thrombolysis and might be preferred to systemic thrombolysis. During the two-year follow-up of the ATTRACT study, a significant improvement was found in the quality of life scores in patients who underwent pharmacomechanical thrombolysis. ${ }^{[65]}$ However, this effect could not be demonstrated in the femoropopliteal region. ${ }^{[6]}$

Approximately half of the patients undergoing pharmacomechanical thrombolysis require an additional intervention. ${ }^{[67]}$ Venous balloon dilatation and stenting may be required, particularly for proximal occlusive lesions. Therefore, a close follow-up is recommended in the early period after treatment, specifically in the first few weeks. The absolute and relative contraindications of thrombolytic therapy are summarized in Table 6.

\section{Inferior vena cava (IVC) filter}

The routine use of IVC filters in addition to anticoagulant therapy is not recommended in patients with DVT. In the PREPIC 2 study, there was no decrease in recurrent PE rates after three months with an IVC filter ${ }^{\left[{ }^{[8]}\right.}$ On the other hand, a numerical increase in the mortality and DVT rates was found in cases in whom the filter was used. Recommendations are summarized below in the light of the 2020
Society of Interventional Radiology guideline and the experience of our country. ${ }^{[69]}$

\section{Do early mobilization and compression stockings reduce the incidence of postthrombotic syndrome?}

No reduction in PTS was observed with the use of compression stockings in a large-scale study reported by Kahn et al. ${ }^{[70]}$ Therefore, the 2016 American College of Chest Physicians (ACCP) guidelines does not recommend the use of compression stockings to decrease the possibility of PTS. However, in the 2021 ESVS guideline, multiple bandages or compression stockings (30 to $40 \mathrm{mmHg}$ ) are recommended within the first $24 \mathrm{~h}$ to reduce pain, edema, and residual obstruction in proximal DVT cases. In addition, if symptoms and signs are limited in proximal DVT cases, knee-length compression stockings are recommended for 6 to 12 months. ${ }^{[71]}$

\section{Venous thromboembolism in the presence of thrombophilia}

Congenital and acquired hematological pathologies as VTE risk factors are summarized in Table 7. Recommendations on this issue are summarized in the G-14 title.

\section{Recommendation G-13}

\begin{tabular}{|l|c|c|l|}
\hline Recommendation & Grade & Level of evidence & Key references \\
\hline $\begin{array}{l}\text { Multiple bandages or compression stockings } \\
(30-40 \mathrm{mmHg}) \text { may be considered within } \\
\text { the first } 24 \text { hours to reduce pain, edema and } \\
\text { residual obstruction in proximal DVT cases. }\end{array}$ & $\begin{array}{c}\text { Weak recommendation } \\
\text { (IIb) }\end{array}$ & B Amin et al. ${ }^{[72]}$ \\
\hline $\begin{array}{l}\text { If symptoms and signs are limited in proximal } \\
\text { DVT cases, knee-length compression stocking } \\
\text { may be considered for 6-12 months. }\end{array}$ & $\begin{array}{c}\text { Weak recommendation } \\
\text { (IIb) }\end{array}$ & B & $\begin{array}{l}\text { Ten Cate-Hoeke } \\
\text { et al. }{ }^{[71]}\end{array}$ \\
\hline DVT: Deep vein thrombosis. & & & \\
\hline
\end{tabular}


Table 7. Frequency of VTE in common hematological disorders

\begin{tabular}{lccc}
\hline & $\begin{array}{c}\text { Frequency } \\
\text { in the population (\%) }\end{array}$ & $\begin{array}{c}\text { Frequency } \\
\text { of VTE cases (\%) }\end{array}$ & $\begin{array}{c}\text { Relative risk } \\
\text { increase }\end{array}$ \\
\hline Heterozygous AT & 0.02 & 1 & $10-30$ \\
Heterozygous PC & $0.2-0.5$ & $1-3$ & 10 \\
Homozygous PC & & $1-2$ & Very high-risk increase \\
Heterozygous PS & $0.1-0.7$ & & 8 \\
Homozygous PS & & $20-20$ & Very high-risk increase \\
Heterozygous Factor V Leiden & $2-15$ & & $3-7$ \\
Homozygous Factor V Leiden & $0.06-0.25$ & $3-5$ & 80 \\
Heterozygous Factor II G202110A & $1-2$ & Rare & $3-7$ \\
Homozygous Factor II G202110A & Rare & 25 & $10-20$ \\
Factor VIII >150\% & 11 & 10 & 2 \\
MTHFR polymorphism (homocysteine $\uparrow)$ & 5 & $4-15$ & 1.5 \\
Antiphospholipid syndrome & 2 & Rare & $7-10$ \\
Dysfibrinogenemia & Rare & Rare & $5-7$ \\
Paroxysmal nocturnal hemoglobinuria & $1-9 / 100000$ & $3-5$ \\
\hline
\end{tabular}

VTE: Venous thromboembolism; AT: Antithrombin; PC: Protein C; PS: Protein S; MTHFR: Methylenetetrahydrofolate reductase.

\section{Recommendation G-14}

\begin{tabular}{|c|c|c|c|}
\hline Recommendation & Grade & Level of evidence & Key references \\
\hline $\begin{array}{l}\text { In the presence of DVT }+ \text { thrombophilia } \\
\text { (antiphospholipid syndrome, homozygous } \\
\text { factor V Leiden mutation, protein C, S and } \\
\text { antithrombin deficiency), periodic evaluation } \\
\text { and full dose extended anticoagulation is } \\
\text { recommended. }\end{array}$ & $\begin{array}{l}\text { Very strong recommendation } \\
\text { (I) }\end{array}$ & $\mathrm{C}$ & $\begin{array}{l}\text { Malec et al. } .^{73]} \\
\text { Stevens et al. } .^{[74]}\end{array}$ \\
\hline $\begin{array}{l}\text { DOAC should not be used in the presence of } \\
\text { DVT and antiphospholipid syndrome. }\end{array}$ & $\begin{array}{l}\text { Not recommended } \\
\text { (III) }\end{array}$ & $\mathrm{C}$ & Malec et al..$^{[73]}$ \\
\hline
\end{tabular}

\section{Declaration of conflicting interests}

The authors declared no conflicts of interest with respect to the authorship and/or publication of this article.

\section{Funding}

The authors received no financial support for the research and/or authorship of this article.

\section{REFERENCES}

1. Heit JA, Spencer FA, White RH. The epidemiology of venous thromboembolism. J Thromb Thrombolysis 2016;41:3-14.

2. Kakkos SK, Gohel M, Baekgaard N, Bauersachs R, BellmuntMontoya S, Black SA, et al. Editor's choice - European Society for Vascular Surgery (ESVS) 2021 clinical practice guidelines on the management of venous thrombosis. Eur $\mathbf{J}$ Vasc Endovasc Surg 2021;61:9-82.

3. Polat A, Akay HT, Köksal C, Bozkurt AK, editörler. Damar.
İstanbul: Bayçınar Tıbbi Yayıncılık; 2019.

4. Wittens C, Davies AH, Bækgaard N, Broholm R, Cavezzi A, Chastanet S, et al. Editor's choice - management of chronic venous disease: Clinical practice guidelines of the European Society for Vascular Surgery (ESVS). Eur J Vasc Endovasc Surg 2015;49:678-737.

5. Kearon C, Akl EA, Ornelas J, Blaivas A, Jimenez D, Bounameaux $\mathrm{H}$, et al. Antithrombotic therapy for VTE disease: CHEST guideline and expert panel report. Chest 2016;149:315-52.

6. Moll S. Thrombophilia: Clinical-practical aspects. J Thromb Thrombolysis 2015;39:367-78.

7. Prandoni P, Lensing AW, Prins MH, Pesavento R, Piccioli A, Sartori MT, et al. The impact of residual thrombosis on the long-term outcome of patients with deep venous thrombosis treated with conventional anticoagulation. Semin Thromb Hemost 2015;41:133-40. 
8. Kearon C, Akl EA, Comerota AJ, Prandoni P, Bounameaux $\mathrm{H}$, Goldhaber SZ, et al. Antithrombotic therapy for VTE disease: Antithrombotic therapy and prevention of thrombosis, 9th ed: American College of Chest Physicians evidence-based clinical practice guidelines. Chest 2012;141(2 Suppl):e419S-e496S.

9. Ortel TL, Neumann I, Ageno W, Beyth R, Clark NP, Cuker A, et al. American Society of Hematology 2020 guidelines for management of venous thromboembolism: Treatment of deep vein thrombosis and pulmonary embolism. Blood Adv 2020;4:4693-738.

10. Othieno R, Okpo E, Forster R. Home versus in-patient treatment for deep vein thrombosis. Cochrane Database Syst Rev 2018;1:CD003076.

11. Becattini C, Agnelli G. Treatment of venous thromboembolism with new anticoagulant agents. J Am Coll Cardiol 2016;67:1941-55.

12. Ertaş F, Kaya H, Kaya Z, Bulur S, Köse N, Gül M, et al. Epidemiology of atrial fibrillation in Turkey: Preliminary results of the multicenter AFTER study. Turk Kardiyol Dern Ars 2013;41:99-104.

13. Sargin M, Tasdemir MM, Kuplay H, Erdogan SB, Tandogar N, Akansel S, et al. Retrospective cohort study for evaluating the INR monitoring patterns in patients with deep vein thrombosis in daily practice: Analysis of 2010-2013 database of a tertiary care center. Phlebology 2019;34:317-23.

14. Sargin M, Erdogan SB, Bastopcu M, Arslanhan G, Tasdemir MM, Orhan G. Cost of healthcare associated with deep vein thrombosis in patients treated with Warfarin in Turkey: 20102013 database analysis of a tertiary care center. Value Health Reg Issues 2019;19:81-6.

15. Budnitz DS, Lovegrove MC, Shehab N, Richards CL. Emergency hospitalizations for adverse drug events in older Americans. N Engl J Med 2011;365:2002-12.

16. Kakkos SK, Kirkilesis GI, Tsolakis IA. Editor's choice efficacy and safety of the new oral anticoagulants dabigatran, rivaroxaban, apixaban, and edoxaban in the treatment and secondary prevention of venous thromboembolism: A systematic review and meta-analysis of phase III trials. Eur J Vasc Endovasc Surg 2014;48:565-75.

17. Delluc A, Ianotto JC, Tromeur C, De Moreuil C, Couturaud F, Lacut K, et al. Real-world incidence of cancer following a first unprovoked venous thrombosis: Results from the EPIGETBO study. Thromb Res 2018;164:79-84.

18. Klein A, Shepshelovich D, Spectre G, Goldvaser H, Raanani P, Gafter-Gvili A. Screening for occult cancer in idiopathic venous thromboembolism - systemic review and metaanalysis. Eur J Intern Med 2017;42:74-80.

19. Lyman GH, Carrier M, Ay C, Di Nisio M, Hicks LK, Khorana AA, et al. American Society of Hematology 2021 guidelines for management of venous thromboembolism: Prevention and treatment in patients with cancer. Blood Adv 2021;5:927-74.

20. Lee AY, Levine MN, Baker RI, Bowden C, Kakkar AK, Prins $\mathrm{M}$, et al. Low-molecular-weight heparin versus a coumarin for the prevention of recurrent venous thromboembolism in patients with cancer. N Engl J Med 2003;349:146-53.
21. Khorana AA, McCrae KR, Milentijevic D, Fortier J, Nelson WW, Laliberté F, et al. Current practice patterns and patient persistence with anticoagulant treatments for cancerassociated thrombosis. Res Pract Thromb Haemost 2017;1:1422.

22. Lee AYY, Kamphuisen PW, Meyer G, Bauersachs R, Janas MS, Jarner MF, et al. Tinzaparin vs Warfarin for treatment of acute venous thromboembolism in patients with active cancer: A randomized clinical trial. JAMA 2015;314:677-86.

23. Kirkilesis GI, Kakkos SK, Tsolakis IA. Editor's choice - a systematic review and meta-analysis of the efficacy and safety of anticoagulation in the treatment of venous thromboembolism in patients with cancer. Eur J Vasc Endovasc Surg 2019;57:685-701.

24. Raskob GE, van Es N, Verhamme P, Carrier M, Di Nisio M, Garcia D, et al. Edoxaban for the treatment of cancerassociated venous thromboembolism. N Engl J Med 2018;378:615-24.

25. Marshall A, Levine M, Hill C, Hale D, Thirlwall J, Wilkie V, et al. Treatment of cancer-associated venous thromboembolism: 12-month outcomes of the placebo versus rivaroxaban randomization of the SELECT-D Trial (SELECT-D: 12m). J Thromb Haemost 2020;18:905-15.

26. McBane RD 2nd, Wysokinski WE, Le-Rademacher JG, Zemla T, Ashrani A, Tafur A, et al. Apixaban and dalteparin in active malignancy-associated venous thromboembolism: The ADAM VTE trial. J Thromb Haemost 2020;18:411-21.

27. Agnelli G, Becattini C, Meyer G, Muñoz A, Huisman MV, Connors JM, et al. Apixaban for the treatment of venous thromboembolism associated with cancer. $\mathrm{N}$ Engl J Med 2020;382:1599-607.

28. Ageno W, Vedovati MC, Cohen A, Huisman M, Bauersachs $\mathrm{R}$, Gussoni $\mathrm{G}$, et al. Bleeding with apixaban and dalteparin in patients with cancer-associated venous thromboembolism: Results from the Caravaggio study. Thromb Haemost 2021;121:616-24.

29. Greer IA, Nelson-Piercy C. Low-molecular-weight heparins for thromboprophylaxis and treatment of venous thromboembolism in pregnancy: A systematic review of safety and efficacy. Blood 2005;106:401-7.

30. Douketis J, Tosetto A, Marcucci M, Baglin T, Cosmi B, Cushman M, et al. Risk of recurrence after venous thromboembolism in men and women: Patient level metaanalysis. BMJ 2011;342:d813.

31. Kearon C, Spencer FA, O'Keeffe D, Parpia S, Schulman $\mathrm{S}$, Baglin T, et al. D-dimer testing to select patients with a first unprovoked venous thromboembolism who can stop anticoagulant therapy: A cohort study. Ann Intern Med 2015;162:27-34.

32. Hokusai-VTE Investigators, Büller HR, Décousus $H$, Grosso MA, Mercuri M, Middeldorp S, et al. Edoxaban versus warfarin for the treatment of symptomatic venous thromboembolism. N Engl J Med 2013;369:1406-15.

33. Schulman S, Kearon C, Kakkar AK, Schellong S, Eriksson $\mathrm{H}$, Baanstra D, et al. Extended use of dabigatran, warfarin, or placebo in venous thromboembolism. N Engl J Med 2013;368:709-18. 
34. Romualdi E, Donadini MP, Ageno W. Oral rivaroxaban after symptomatic venous thromboembolism: The continued treatment study (EINSTEIN-extension study). Expert Rev Cardiovasc Ther 2011;9:841-4.

35. Weitz JI, Lensing AWA, Prins MH, Bauersachs R, BeyerWestendorf J, Bounameaux H, et al. Rivaroxaban or Aspirin for extended treatment of venous thromboembolism. N Engl J Med 2017;376:1211-22.

36. Agnelli G, Buller HR, Cohen A, Curto M, Gallus AS, Johnson M, et al. Apixaban for extended treatment of venous thromboembolism. N Engl J Med 2013;368:699-708.

37. Raskob G, Ageno W, Cohen AT, Brekelmans MP, Grosso MA, Segers A, et al. Extended duration of anticoagulation with edoxaban in patients with venous thromboembolism: A post-hoc analysis of the Hokusai-VTE study. Lancet Haematol 2016;3:e228-36.

38. Becattini C, Agnelli G, Schenone A, Eichinger S, Bucherini E, Silingardi M, et al. Aspirin for preventing the recurrence of venous thromboembolism. N Engl J Med 2012;366:1959-67.

39. Brighton TA, Eikelboom JW, Mann K, Mister R, Gallus A, Ockelford P, et al. Low-dose aspirin for preventing recurrent venous thromboembolism. N Engl J Med 2012;367:1979-87.

40. Simes J, Becattini C, Agnelli G, Eikelboom JW, Kirby AC, Mister R, et al. Aspirin for the prevention of recurrent venous thromboembolism: The INSPIRE collaboration. Circulation 2014;130:1062-71.

41. Bozkurt AK, editör. Periferik Arter ve Ven Hastalıkları Ulusal Tedavi Kılavuzu 2016. İstanbul: Bayçınar Tibbi Yayıncılık; 2016.

42. Prins MH, Lensing AWA, Prandoni P, Wells PS, Verhamme $\mathrm{P}$, Beyer-Westendorf $\mathrm{J}$, et al. Risk of recurrent venous thromboembolism according to baseline risk factor profiles. Blood Adv 2018;2:788-96.

43. Agnelli G, Buller HR, Cohen A, Curto M, Gallus AS, Johnson M, et al. Oral apixaban for the treatment of acute venous thromboembolism. N Engl J Med 2013;369:799-808.

44. Schulman S. How I treat recurrent venous thromboembolism in patients receiving anticoagulant therapy. Blood 2017;129:3285-93.

45. Monagle P, Cuello CA, Augustine C, Bonduel M, Brandão LR, Capman T, et al. American Society of Hematology 2018 Guidelines for management of venous thromboembolism: Treatment of pediatric venous thromboembolism. Blood Adv 2018;2:3292-316.

46. Halton J, Brandão LR, Luciani M, Bomgaars L, Chalmers E, Mitchell LG, et al. Dabigatran etexilate for the treatment of acute venous thromboembolism in children (DIVERSITY): A randomised, controlled, open-label, phase $2 b / 3$, noninferiority trial. Lancet Haematol 2021;8:e22-e33.

47. Young G, Lensing AWA, Monagle P, Male C, Thelen $\mathrm{K}$, Willmann $\mathrm{S}$, et al. Rivaroxaban for treatment of pediatric venous thromboembolism. An Einstein-Jr phase 3 dose-exposure-response evaluation. J Thromb Haemost 2020;18:1672-85.

48. Mujer MTP, Rai MP, Atti V, Dimaandal IL, Chan AS, Shrotriya S, et al. An update on the reversal of nonvitamin $\mathrm{K}$ antagonist oral anticoagulants. Adv Hematol 2020;2020:7636104.
49. Zada I, Wang S, Akerman M, Hanna A. Four-factor prothrombin complex concentrate for the reversal of direct oral anticoagulants. J Intensive Care Med 2021;36:58-62.

50. Tomaselli GF, Mahaffey KW, Cuker A, Dobesh PP, Doherty JU, Eikelboom JW, et al. 2020 ACC expert consensus decision pathway on management of bleeding in patients on oral anticoagulants: A report of the American College of Cardiology solution set oversight committee. J Am Coll Cardiol 2020;76:594-622.

51. Kirkilesis G, Kakkos SK, Bicknell C, Salim S, Kakavia $\mathrm{K}$. Treatment of distal deep vein thrombosis. Cochrane Database Syst Rev 2020;4:CD013422.

52. Galanaud JP, Sevestre MA, Pernod G, Genty C, Richelet S, Kahn SR, et al. Long-term outcomes of cancer-related isolated distal deep vein thrombosis: The OPTIMEV study. J Thromb Haemost 2017;15:907-16.

53. Decousus H, Quéré I, Presles E, Becker F, Barrellier MT, Chanut M, et al. Superficial venous thrombosis and venous thromboembolism: A large, prospective epidemiologic study. Ann Intern Med 2010;152:218-24.

54. Di Nisio M, Wichers IM, Middeldorp S. Treatment for superficial thrombophlebitis of the leg. Cochrane Database Syst Rev 2018;2:CD004982.

55. Duffett L, Kearon C, Rodger M, Carrier M. Treatment of superficial vein thrombosis: A systematic review and metaanalysis. Thromb Haemost 2019;119:479-89.

56. Beyer-Westendorf J, Schellong SM, Gerlach H, Rabe E, Weitz JI, Jersemann K, et al. Prevention of thromboembolic complications in patients with superficial-vein thrombosis given rivaroxaban or fondaparinux: The open-label, randomised, non-inferiority SURPRISE phase $3 \mathrm{~b}$ trial. Lancet Haematol 2017;4:e105-e113.

57. Decousus H, Prandoni P, Mismetti P, Bauersachs RM, Boda Z, Brenner B, et al. Fondaparinux for the treatment of superficial-vein thrombosis in the legs. $\mathrm{N}$ Engl $\mathrm{J}$ Med 2010;363:1222-32.

58. Nikolakopoulos KM, Kakkos SK, Papageorgopoulou CP, Tsolakis IA. Extended-duration treatment of superficial vein thrombosis of the lower limbs with Tinzaparin. Vasc Specialist Int 2018;34:1-9.

59. Houghton DE, Casanegra AI, Peterson LG, Cochuyt J, Hodge DO, Vlazny D, et al. Treatment of upper extremity deep vein thrombosis with apixaban and rivaroxaban. Am J Hematol 2020;95:817-23.

60. Schastlivtsev I, Lobastov K, Tsaplin S, Kanzafarova I, Barinov V, Laberko L, et al. Rivaroxaban in the treatment of upper extremity deep vein thrombosis: A single-center experience and review of the literature. Thromb Res 2019;181:24-8.

61. Illig KA, Doyle AJ. A comprehensive review of PagetSchroetter syndrome. J Vasc Surg 2010;51:1538-47.

62. Enden T, Haig Y, Kløw NE, Slagsvold CE, Sandvik L, Ghanima W, et al. Long-term outcome after additional catheter-directed thrombolysis versus standard treatment for acute iliofemoral deep vein thrombosis (the CaVenT study): A randomised controlled trial. Lancet 2012;379:31-8.

63. Vedantham S, Goldhaber SZ, Julian JA, Kahn SR, Jaff MR, Cohen DJ, et al. Pharmacomechanical catheter-directed 
thrombolysis for deep-vein thrombosis. N Engl J Med 2017;377:2240-52.

64. Notten P, Ten Cate-Hoek AJ, Arnoldussen CWKP, Strijkers RHW, de Smet AAEA, Tick LW, et al. Ultrasound-accelerated catheter-directed thrombolysis versus anticoagulation for the prevention of post-thrombotic syndrome (CAVA): A single-blind, multicentre, randomised trial. Lancet Haematol 2020;7:e40-e49.

65. Kahn SR, Julian JA, Kearon C, Gu CS, Cohen DJ, Magnuson EA, et al. Quality of life after pharmacomechanical catheterdirected thrombolysis for proximal deep venous thrombosis. J Vasc Surg Venous Lymphat Disord 2020;8:8-23.e18.

66. Kearon C, Gu CS, Julian JA, Goldhaber SZ, Comerota AJ, Gornik HL, et al. Pharmacomechanical catheterdirected thrombolysis in acute femoral-popliteal deep vein thrombosis: Analysis from a Stratified randomized trial. Thromb Haemost 2019;119:633-44.

67. Grommes J, Strijkers R, Greiner A, Mahnken AH, Wittens $\mathrm{CH}$. Safety and feasibility of ultrasound-accelerated catheterdirected thrombolysis in deep vein thrombosis. Eur J Vasc Endovasc Surg 2011;41:526-32.

68. Mismetti P. Randomized trial assessing the efficacy of the partial interruption of the inferior vena cava by an optional vena caval filter in the prevention of the recurrence of pulmonary embolism. PREPIC 2 trial: Prevention of embolic recurrences by caval interruption (prospective, multicentric, randomised, open trial). Rev Pneumol Clin 2008;64:328-31.

69. Kaufman JA, Barnes GD, Chaer RA, Cuschieri J, Eberhardt RT, Johnson MS, et al. Society of interventional radiology clinical practice guideline for inferior vena cava filters in the treatment of patients with venous thromboembolic disease: Developed in collaboration with the American College of Cardiology, American College of Chest Physicians, American College of Surgeons Committee on Trauma, American Heart Association, Society for Vascular Surgery, and Society for Vascular Medicine. J Vasc Interv Radiol 2020;31:1529-44.

70. Kahn SR, Shapiro S, Wells PS, Rodger MA, Kovacs MJ, Anderson DR, et al. Compression stockings to prevent postthrombotic syndrome: A randomised placebo-controlled trial. Lancet 2014;383:880-8.

71. Ten Cate-Hoek AJ, Amin EE, Bouman AC, Meijer K, Tick LW, Middeldorp S, et al. Individualised versus standard duration of elastic compression therapy for prevention of post-thrombotic syndrome (IDEAL DVT): A multicentre, randomised, single-blind, allocation-concealed, noninferiority trial. Lancet Haematol 2018;5:e25-e33.

72. Amin EE, Bistervels IM, Meijer K, Tick LW, Middeldorp S, Mostard G, et al. Reduced incidence of vein occlusion and postthrombotic syndrome after immediate compression for deep vein thrombosis. Blood 2018;132:2298-304.

73. Malec K, Broniatowska E, Undas A. Direct oral anticoagulants in patients with antiphospholipid syndrome: A cohort study. Lupus 2020;29:37-44.

74. Stevens SM, Woller SC, Bauer KA, Kasthuri R, Cushman M, Streiff $\mathrm{M}$, et al. Guidance for the evaluation and treatment of hereditary and acquired thrombophilia. J Thromb Thrombolysis 2016;41:154-64. 